\section{Effect of Sugar-based Compounds in Enhancing the Efficacy of Insecticides against the Western Flower Thrips}

\author{
Raymond A. Cloyd ${ }^{1}$ and Joshua D. Gillespie
}

ADDITIONAL INDEX WORDs. Frankliniella occidentalis, sugar enhancement, pesticide efficacy, pesticide additives, floriculture, pest management

SUMMARY. It has been proposed by greenhouse producers that adding sugar to a stomach poison insecticide enhances the efficacy of the insecticide in controlling western flower thrips (Frankliniella occidentalis). As such, a series of laboratory, including no-choice and multiple-choice assays, and greenhouse experiments were conducted to determine if adding sugar-based compounds to insecticides enhances efficacy against western flower thrips. The sugar-based compounds evaluated were Mountain Dew, Diet Mountain Dew, white sugar, and brown sugar at two rates [initial $(0.18 \mathrm{~mL} / 100 \mathrm{~mL}$ and $0.12 \mathrm{~g} / 100 \mathrm{~mL})$ and high $(0.36 \mathrm{~mL} / 100 \mathrm{~mL}$ and $0.24 \mathrm{~g} / 100 \mathrm{~mL})]$. A water control was also included in all the assays. In the laboratory experiments, western flower thrips adults and nymphs were not attracted to any of the sugar-based compounds with $<60 \mathrm{~s}$ (out of $300 \mathrm{~s}$ total) spent in any of the treatments, and $\leq 29 \mathrm{~s}$ (out of $300 \mathrm{~s}$ total) spent in the treatments when the sugar-based compounds were mixed with three insecticides (tau-fluvalinate, pyridalyl, and spinosad). In the greenhouse experiments, the addition of the high rate of Mountain Dew $(0.36 \mathrm{~mL} / 100 \mathrm{~mL})$ and brown sugar $(0.24 \mathrm{~g} / 100 \mathrm{~mL})$ did not enhance the efficacy (based on percent mortality) of the insecticides against western flower thrips. There was no significant difference between the individual insecticide treatments and the mixtures with either Mountain Dew or brown sugar. This study is the first to quantitatively demonstrate that western flower thrips adults and nymphs are not attracted to sugar-based compounds and that it is not warranted to add these types of materials to spray solutions targeted for control of western flower thrips.

W estern flower thrips are the most destructive insect pest of greenhouses worldwide, causing both direct and indirect damage to a wide range of horticultural crops (Brodsgaard, 1989; Gerin et al., 1994; Helyer et al., 1995; Tommasini and Maini, 1995). The primary means of dealing with western flower thrips in greenhouse production systems is the use of insecticides (Herron and James, 2005; Lewis, 1997; Parrella and Murphy, 1996). However, greenhouse producers are continually seeking alternative options to manage or regulate western flower thrips populations to alleviate the prospect of resistance (Georghiou, 1986) and thus preserve already existing commercially available insecticides. Furthermore, it is difficult

Department of Entomology, Kansas State University, 123 Waters Hall, Manhattan, KS 66506-4004

We wish to thank the Fred C. Gloeckner Foundation for providing financial support for this study. In addition, we acknowledge Nikki DePaola for providing technical assistance on the initial phase of the study. Finally, we thank Dr. James R. Nechols and Dr. Kun Yan Zhu of the Department of Entomology at Kansas State University (Manhattan, KS) for their comments on a previous draft of the manuscript.

${ }^{1}$ Corresponding author. E-mail: rcloyd@ksu.edu. to suppress western flower thrips populations because of their thigmotactic behavior, which means that the body is in constant contact with a surface so they tend to occupy narrow crevices in plant parts (Childers, 1997; Kirk, $1997 \mathrm{a}, \mathrm{b})$. This is why western flower thrips tend to reside in tight-enclosed areas including unopened flower buds and terminal buds, which decrease their susceptibility to insecticide sprays (Brodsgaard, 2004; Jensen, 2000; Mound, 1996; Tommasini and Maini, 1995). As such, there has been interest in using materials that lure or attract western flower thrips to increase the efficacy of insecticide spray applications (attract-and-kill strategy).

It has been proposed by greenhouse producers that adding sugar to a stomach poison insecticide enhances the efficacy of the insecticide in controlling western flower thrips (R.A. Cloyd, personal observation). However, there has been no scientific information to support this notion. In fact, a recommendation provided in the 1940s was to use sugar as a feeding stimulant for controlling western flower thrips (Parrella, 1995). This supposedly involved adding sugar (preferably white sugar) with a stomach poison insecticide to enhance the efficacy of the spray solution (Parrella, 1995). In fact, greenhouse producers continually inquire about or suggest that mixing sugar such as white or brown sugar or a sugar-laden soft drink (e.g., Mountain Dew; PepsiCo, Deep Gap, NC) with a contact insecticide (in a spray solution) enhances the efficacy of the spray application against western flower thrips (R.A. Cloyd, unpublished data). Furthermore, it has been suggested that molasses and brown sugar will act as a surfactant or attract thrips from flowers and encourage them to consume or come in contact with insecticide residues (Cloyd, 2009). However, it is difficult to comprehend the basis of this attraction because of the characteristics of sugar and sugar-based compounds.

White sugar is pure sucrose derived from either tropical sugar cane or sugar beets. In contrast, there are two types of brown sugar: sticky and freeflowing. Both types are obtained by adding syrup such as molasses to purified or refined sugar (FitDay-Myth or Fact, 2011). Mountain Dew, which is a sugar-laden soft drink, contains $77 \mathrm{~g}$ of sugar (per bottle) and a multitude of ingredients including carbonated water and high-fructose corn syrup. As such,

\begin{tabular}{lllc}
\hline $\begin{array}{l}\text { Units } \\
\begin{array}{l}\text { To convert U.S. to SI, } \\
\text { multiply by }\end{array}\end{array}$ & U.S. unit & SI unit & $\begin{array}{l}\text { To convert SI to U.S., } \\
\text { multiply by }\end{array}$ \\
\hline 29.5735 & $\mathrm{fl} \mathrm{oz}$ & $\mathrm{mL}$ & 0.0338 \\
0.0781 & $\mathrm{fl} \mathrm{oz} / 100 \mathrm{gal}$ & $\mathrm{mL} \cdot \mathrm{L}^{-1}$ & 12.8000 \\
0.7813 & $\mathrm{fl} \mathrm{oz} / \mathrm{gal}$ & $\mathrm{mL} / 100 \mathrm{~mL}$ & 1.2800 \\
0.3048 & $\mathrm{ft}$ & $\mathrm{m}$ & 3.2808 \\
2.54 & inch $(\mathrm{es})$ & $\mathrm{cm}$ & 0.3937 \\
25.4 & inch $(\mathrm{es})$ & $\mathrm{mm}$ & 0.0394 \\
28.3495 & $\mathrm{oz}$ & $\mathrm{g}$ & 0.0353 \\
0.0749 & $\mathrm{oz} / 100 \mathrm{gal}$ & $\mathrm{g} \cdot \mathrm{L}^{-1}$ & 13.3526 \\
0.7489 & $\mathrm{oz} / \mathrm{gal}$ & $\mathrm{g} / 100 \mathrm{~mL}$ & 1.3353 \\
0.9464 & $\mathrm{qt}$ & $\mathrm{L}$ & 1.0567
\end{tabular}


it is difficult to understand how and why a plant-feeding insect such as western flower thrips, which primarily feeds on pollen and plant tissue (Kirk, 1985, 1987; Trichilo and Leigh, 1988), would be attracted to any type of sugar, particularly if the sugar does not provide any essential nutrients (proteins and amino acids) required for development and reproduction (Kirk, 1987). However, there are no quantitative studies that have actually substantiated claims made regarding using sugar or sugar-based compounds with contact insecticides to enhance efficacy against western flower thrips. Therefore, the objective of this study was to determine if sugar-based compounds are attractive to and improve control of western flower thrips when mixed with insecticides under both laboratory and greenhouse conditions.

\section{Materials and methods}

LABORATORY EXPERIMENTS. These experiments involved both nochoice and multiple-choice assays and were designed to determine whether different sugar-based compounds were directly attractive to the adult and nymphal stages of the western flower thrips using two different rates of each compound tested. The compound treatments were white sugar (C\&H Sugar Co., Crockett, CA), brown sugar, Mountain Dew, Diet Mountain Dew (PepsiCo), and a water control. The designated compounds were measured to exact quantities and then mixed thoroughly in $100 \mathrm{~mL}$ of distilled water. The rates included $0.12 \mathrm{~g} / 100 \mathrm{~mL}$ white sugar, $0.12 \mathrm{~g} / 100 \mathrm{~mL}$ brown sugar, $0.18 \mathrm{~mL} / 100 \mathrm{~mL}$ Mountain Dew, and $0.18 \mathrm{~mL} / 100 \mathrm{~mL}$ Diet Mountain Dew. These rates were used based on inquires and feedback from greenhouse producers (R.A. Cloyd, unpublished data). We also conducted similar assays (described below) using higher (2-fold) rates: $0.24 \mathrm{~g} / 100 \mathrm{~mL}$ white sugar, $0.24 \mathrm{~g} / 100 \mathrm{~mL}$ brown sugar, $0.36 \mathrm{~mL} / 100 \mathrm{~mL}$ Mountain Dew, and $0.36 \mathrm{~mL} / 100 \mathrm{~mL}$ Diet Mountain Dew. Each treatment was replicated 10 times per each western flower thrips life stage (adult and nymph).

For the no-choice assay, only one compound was used, whereas all four were included in the multiple-choice assays. In addition, a water control was included in all the assays. The experiments were initiated by mixing 10
Table 1. Sugar-based compounds including Mountain Dew (PepsiCo, North Gap, NC), Diet Mountain Dew, white sugar, and brown sugar and insecticides used and rates evaluated against western flower thrips in Expts. 1 and 2.

\begin{tabular}{lc}
\hline & Expt. 1 \\
\hline Treatment & Rate (per quart) \\
\hline Mountain Dew (high rate) & $1.70 \mathrm{~mL}$ \\
Diet Mountain Dew (high rate) & $1.70 \mathrm{~mL}$ \\
White sugar (high rate) & $1.13 \mathrm{~g}$ \\
Brown sugar (high rate) & $1.13 \mathrm{~g}$ \\
Mountain Dew (initial rate) & $0.85 \mathrm{~mL}$ \\
Diet Mountain Dew (initial rate) & $0.85 \mathrm{~mL}$ \\
White sugar (initial rate) & $0.56 \mathrm{~g}$ \\
Brown sugar (initial rate) & $0.56 \mathrm{~g}$ \\
Untreated control & -
\end{tabular}

Expt. 2

\begin{tabular}{lc}
\hline Treatment & Rate $(\text { per quart })^{\mathbf{z}}$ \\
\hline Spinosad & $0.44 \mathrm{~mL}$ \\
Abamectin & $0.59 \mathrm{~mL}$ \\
Azadirachtin & $0.59 \mathrm{~mL}$ \\
Sucrose octanoate ester & $7.39 \mathrm{~mL}$ \\
Mountain Dew & $26.8 \mathrm{~mL}$ \\
Spinosad + Mountain Dew & $0.44 \mathrm{~mL}+26.8 \mathrm{~mL}$ \\
Abamectin + Mountain Dew & $0.59 \mathrm{~mL}+26.8 \mathrm{~mL}$ \\
Azadirachtin + Mountain Dew & $0.59 \mathrm{~mL}+26.8 \mathrm{~mL}$ \\
Untreated control & - \\
\hline${ }^{2} 1 \mathrm{~mL} / \mathrm{qt}=0.1353 \mathrm{fl} \mathrm{oz} / \mathrm{gal}=1.0567 \mathrm{~mL} \cdot \mathrm{L}^{-1}, \mathrm{lg} / \mathrm{qt}=0.1411 \mathrm{oz} / \mathrm{gal}=1.0567 \mathrm{~g} \cdot \mathrm{L}^{-1}$. &
\end{tabular}

Table 2. Rates of insecticides [tau-fluvalinate at $8.0 \mathrm{fl} \mathrm{oz} / 100 \mathrm{gal}(\mathbf{0 . 6 2 5}$ $\left.\mathrm{mL} \cdot \mathrm{L}^{-1}\right)$, pyridalyl at $8.0 \mathrm{oz} / 100 \mathrm{gal}\left(0.599 \mathrm{~g} \cdot \mathrm{L}^{-1}\right)$, and spinosad at $6.0 \mathrm{fl} \mathrm{oz} / 100$ gal $\left.\left(0.468 \mathrm{~mL} \cdot \mathrm{L}^{-1}\right)\right]$, and high rate $(\mathrm{HR})$ and initial rate $(\mathrm{IR})$ of Mountain Dew (PepsiCo, Deep Gap, NC) $[0.36 \mathrm{~mL} / 100 \mathrm{~mL}(0.4608 \mathrm{fl} \mathrm{oz} / \mathrm{gal})$ and $0.18 \mathrm{~mL} /$ $100 \mathrm{gal}(0.2304 \mathrm{fl} \mathrm{oz} / \mathrm{gal})]$ and brown sugar $[0.24 \mathrm{~g} / 100 \mathrm{~mL}(0.3204 \mathrm{oz} / \mathrm{gal})$ and $0.12 \mathrm{~g} / 100 \mathrm{~mL}(0.1602 \mathrm{oz} / \mathrm{gal})]$ used in Expts. 3 and 4.

\begin{tabular}{ll}
\hline & Expt. 3 \\
\hline Treatment & Rate (per quart) \\
\hline Tau-fluvalinate & $0.51 \mathrm{~mL}$ \\
Pyridalyl & $0.56 \mathrm{~g}$ \\
Spinosad & $0.44 \mathrm{~mL}$ \\
Tau-fluvalinate + Mountain Dew (HR) & $0.51 \mathrm{~mL}+3.4 \mathrm{~mL}$ \\
Pyridalyl + Mountain Dew (HR) & $0.56 \mathrm{~g}+3.4 \mathrm{~mL}$ \\
Spinosad + Mountain Dew (HR) & $0.44 \mathrm{~mL}+3.4 \mathrm{~mL}$ \\
Tau-fluvalinate + Mountain Dew (IR) & $0.51 \mathrm{~mL}+1.7 \mathrm{~mL}$ \\
Pyridalyl + Mountain Dew (IR) & $0.56 \mathrm{~g}+1.7 \mathrm{~mL}$ \\
Spinosad + Mountain Dew (IR) & $0.44 \mathrm{~mL}+1.7 \mathrm{~mL}$
\end{tabular}

Expt. 4

\begin{tabular}{ll}
\hline Treatment & Rate (per quart) \\
\hline Tau-fluvalinate & $0.51 \mathrm{~mL}$ \\
Pyridalyl & $0.56 \mathrm{~g}$ \\
Spinosad & $0.44 \mathrm{~mL}$ \\
Tau-fluvalinate + brown sugar (HR) & $0.51 \mathrm{~mL}+1.1 \mathrm{~g}$ \\
Pyridalyl + brown sugar (HR) & $0.56 \mathrm{~g}+1.1 \mathrm{~g}$ \\
Spinosad + brown sugar (HR) & $0.44 \mathrm{~mL}+1.1 \mathrm{~g}$ \\
Tau-fluvalinate + brown sugar (IR) & $0.51 \mathrm{~mL}+0.56 \mathrm{~g}$ \\
Pyridalyl + brown sugar (IR) & $0.56 \mathrm{~g}+0.56 \mathrm{~g}$ \\
Spinosad + brown sugar (IR) & $0.44 \mathrm{~mL}+0.56 \mathrm{~g}$ \\
Untreated control & -
\end{tabular}

${ }^{2} 1 \mathrm{~mL} / \mathrm{qt}=0.1353 \mathrm{fl} \mathrm{oz} / \mathrm{gal}=1.0567 \mathrm{~mL} \cdot \mathrm{L}^{-1}, \mathrm{l} \mathrm{g} / \mathrm{qt}=0.1411 \mathrm{oz} / \mathrm{gal}=1.0567 \mathrm{~g} \cdot \mathrm{L}^{-1}$ 
solutions of each compound treatment at the designated rates. There were 10 replications per compound treatment. Then, 10 petri dishes were prepared by excising five circles $(2-\mathrm{cm}$ diameter) from filter paper (Whatman No. 1; Whatman, Maidston, England). The five circles of filter paper were placed into each petri dish, where the treatments were to be applied. The circles were placed equidistant from each other into each petri dish. After preparing the solutions and petri dishes, one drop of each treatment, using a micropipette, was placed on the filter paper circle, which was enough to sufficiently moisten the filter paper. Then, an individual western flower thrips adult or nymph, collected from a laboratory-reared colony ( $\approx 2$ weeks in age) maintained at Kansas State University (Manhattan), was positioned in the center of each petri dish. Similaraged adults and nymphs (3-d old) were used within $12 \mathrm{~h}$ of initiating the experiments. Five-minute (300 s) observations were made of each petri dish (10 replicates total). Thrips movement was monitored throughout the entire length of time, and the amount of time that each life stage visited a treatment was recorded. The experiments were conducted under typical laboratory lighting (overhead ceiling lights).

To avoid positional effects, treatments were rotated so that they were located in different positions within the petri dishes. In addition, we conducted preliminary experiments to compare attraction and retention time of western flower thrips adults and nymphs to water, Mountain Dew, and brown sugar, on filter paper and leaf disks (1-cm diameter) of chrysanthemum (Tanacetum grandiflora). We found that there was no difference in either attraction or retention time between the two surfaces associated with the water control and sugar-based compound treatments (data not shown). As such, we were justified in using filter paper in all of the experiments.

The assays were repeated using three different insecticides including tau-fluvalinate at $8.0 \mathrm{fl} \mathrm{oz} / 100 \mathrm{gal}$ (Mavrik Aquaflow ${ }^{\circledR}$; Wellmark International, Schaumburg, IL), pyridalyl at $8.0 \mathrm{oz} / 100 \mathrm{gal}\left(\right.$ Overture $^{\circledR}$; Valent U.S.A. Corp., Walnut Creek, CA), and spinosad at $6.0 \mathrm{fl} \mathrm{oz} / 100 \mathrm{gal}$ (Conserve $^{\circledR}$; Dow AgroSciences, Indianapolis, IN). These insecticide treatments were combined with the initial and high rates of all four sugar-based compounds.

Greenhouse EXPERIMENTS. All experiments were conducted in a glasscovered greenhouse, and the procedures were similar for the four experiments. Yellow cut transvaal daisy (Gerbera jamesonii) flowers were obtained from

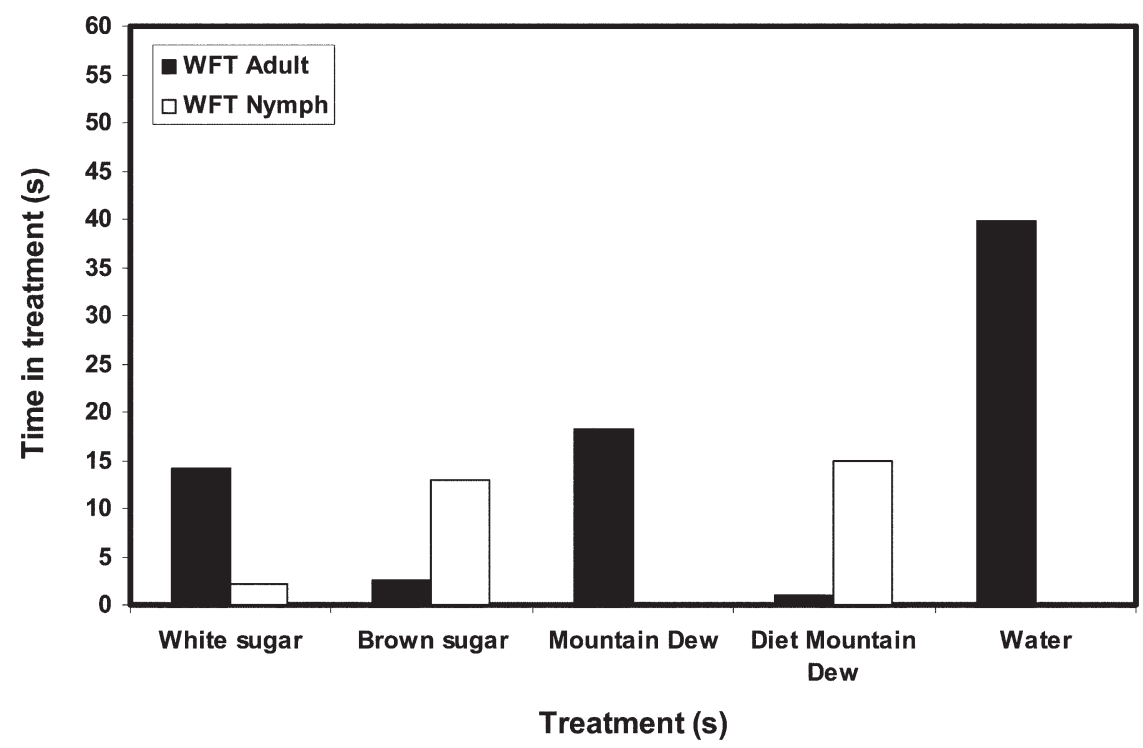

Fig. 1. Time spent (out of $300 \mathrm{~s}$ total) by western flower thrips (WFT) adult (black bars) and nymph (white bars) in each of the treatments (at the initial rates) associated with the no-choice bioassays. Rates used were Mountain Dew (PepsiCo, Deep Gap, NC) at $0.18 \mathrm{~mL} / 100 \mathrm{~mL}(0.2304 \mathrm{fl} \mathrm{oz} / \mathrm{gal})$, Diet Mountain Dew at $0.18 \mathrm{~mL} / 100 \mathrm{~mL}$, white sugar at $0.12 \mathrm{~g} / 100 \mathrm{~mL}(0.1602 \mathrm{oz} / \mathrm{gal})$, and brown sugar at $0.12 \mathrm{~g} / 100 \mathrm{~mL}$.

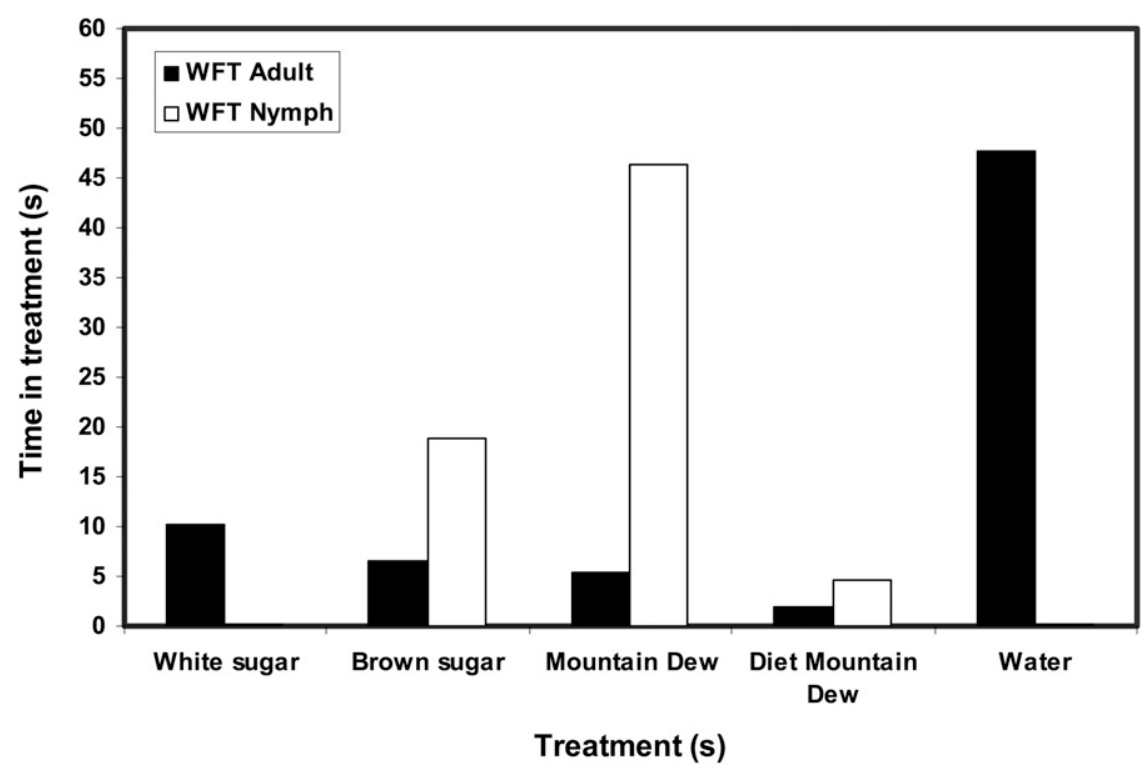

Fig. 2. Time spent (out of $300 \mathrm{~s}$ total) by western flower thrips (WFT) adult (black bars) and nymph (white bars) in each of the treatments (at the high rates) associated with the no-choice bioassays. Rates used were Mountain Dew (PepsiCo, Deep Gap, $\mathrm{NC})$ at $0.36 \mathrm{~mL} / 100 \mathrm{~mL}(0.4608 \mathrm{fl} \mathrm{oz} / \mathrm{gal})$, Diet Mountain Dew at $0.36 \mathrm{~mL} / 100$ $\mathrm{mL}$, white sugar at $0.24 \mathrm{~g} / 100 \mathrm{~mL}(0.3204 \mathrm{oz} / \mathrm{gal})$, and brown sugar at $0.24 \mathrm{~g} /$ $100 \mathrm{~mL}$. 
below the base of the flowers and placed into $22-\mathrm{mm}$, low-background borosilicate glass vials containing tap water. One transvaal daisy cut flower was placed into each glass vial. The glass vials were inserted into plastic containers $(250 \mathrm{~mL})$ with sand, which held the glass vial containing the tap water and the cut flower upright during the experiments. One container or cut flower was equal to one experimental unit.

All the plastic containers, with the cut flowers, were positioned in a polyvinyl chloride (PVC) pipe open frame on a wire-mesh bench $(16 \times$ $5 \mathrm{ft}$ ), and the designated treatment containers, with the cut flowers, were arranged in a completely randomized design. A 50\% black knit shadecloth (Hummert International, Earth City, MO) was positioned over the PVC frame to protect the cut flowers from direct sunlight and thus preserve their longevity. Each cut flower was artificially infested with $\approx 15$ to 20 western flower thrips (90\% adults and 10\% nymphs) obtained from a laboratoryreared colony in the Department of Entomology at Kansas State University (Manhattan).

All flowers were sprayed with the appropriate treatments using a 1-quart plastic spray bottle (The Home Depot, Manhattan, KS) 2 d after postinfestation. Each flower was sprayed to runoff with $\approx 15 \mathrm{~mL}$ of spray solution. This spray volume thoroughly saturated the flower surface and allowed the spray solution to penetrate into the disk portion of the flowers. The glass vials were refilled regularly with tap water to ensure lasting quality of the cut flowers. The temperature inside the greenhouse during all experiments was $21 \pm 3{ }^{\circ} \mathrm{C}$ with a relative humidity between $50 \%$ and $60 \%$.

Four experiments were conducted with different treatment combinations, replicated five times. In Expt. 1 in which we only evaluated the sugarbased compounds, there were a total of nine treatments with five replications per treatment. The treatments and rates are presented in Table 1. In Expt. 2, we evaluated four individual insecticides and combinations with one rate of Mountain Dew $(26.8 \mathrm{~mL} / 100 \mathrm{~mL})$. There were five replications per treatment. The insecticides used were spinosad, abamectin (Avid ${ }^{\circledR}$; Syngenta Crop Protection, Greensboro, NC), azadirachtin $\left(\right.$ Ornazin $^{\circledR}$; SePRO Corp.,
Carmel, IN), and sucrose octanoate ester (SucraShield ${ }^{\mathrm{TM}}$; Natural Forces, Davidson, NC). Table 1 presents the materials and rates used in Expt. 2.

Expts. 3 and 4 used three different insecticides: tau-fluvalinate at 8.0 fl oz/100 gal (Mavrik Aquaflow ${ }^{\circledR}$ ), pyridalyl at $8.0 \mathrm{oz} / 100 \mathrm{gal}$ (Overture $\left.^{\circledR}\right)$, and spinosad at $6.0 \mathrm{fl} \mathrm{oz} / 100$ gal $\left(\right.$ Conserve $\left.^{\circledR}\right)$. There were five replications per treatment. The insecticides were applied individually and combined with the initial or high rate of either Mountain Dew (1.7 or $3.4 \mathrm{~mL} / \mathrm{qt}$ ) or

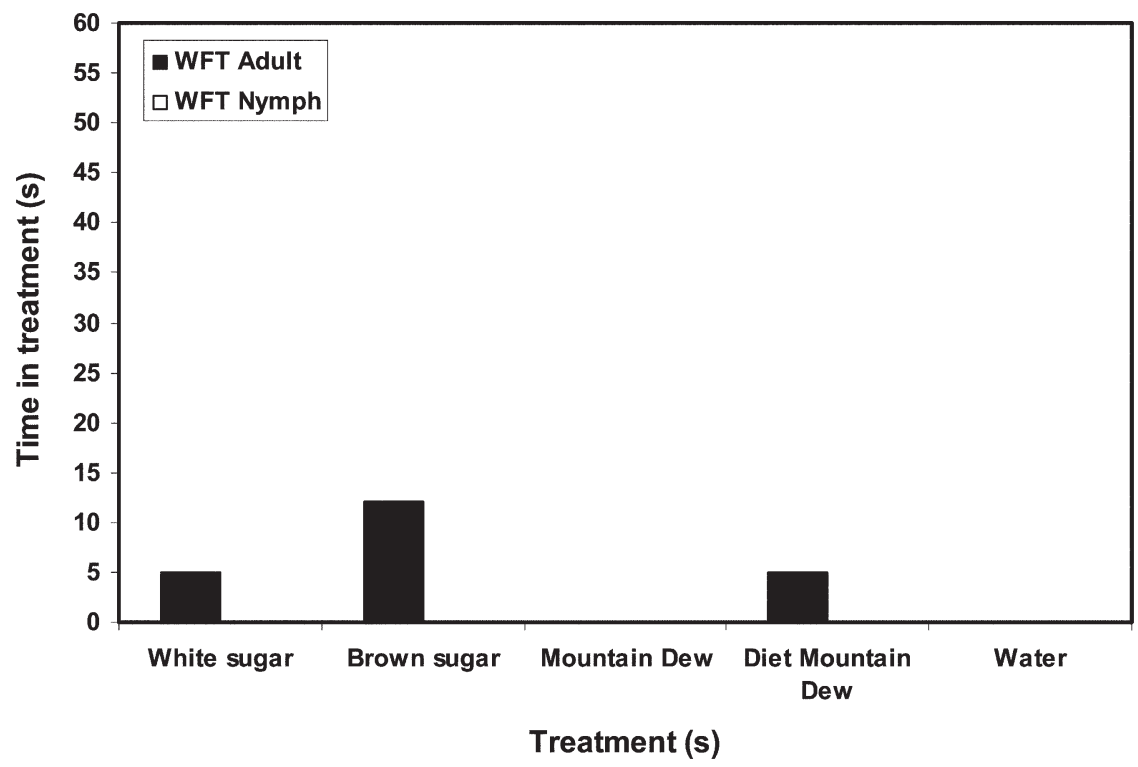

Fig. 3. Time spent (out of $300 \mathrm{~s}$ total) by western flower thrips (WFT) adult (black bars) and nymph (white bars) in each of the treatments (at the initial rates) associated with the multiple-choice bioassays. Rates used were Mountain Dew (PepsiCo, Deep Gap, NC) at $0.18 \mathrm{~mL} / 100 \mathrm{~mL}(0.2304 \mathrm{fl} \mathrm{oz} / \mathrm{gal})$, Diet Mountain Dew at $0.18 \mathrm{~mL} / 100 \mathrm{~mL}$, white sugar at $0.12 \mathrm{~g} / 100 \mathrm{~mL}(0.1602 \mathrm{oz} / \mathrm{gal})$, and brown sugar at $0.12 \mathrm{~g} / 100 \mathrm{~mL}$.

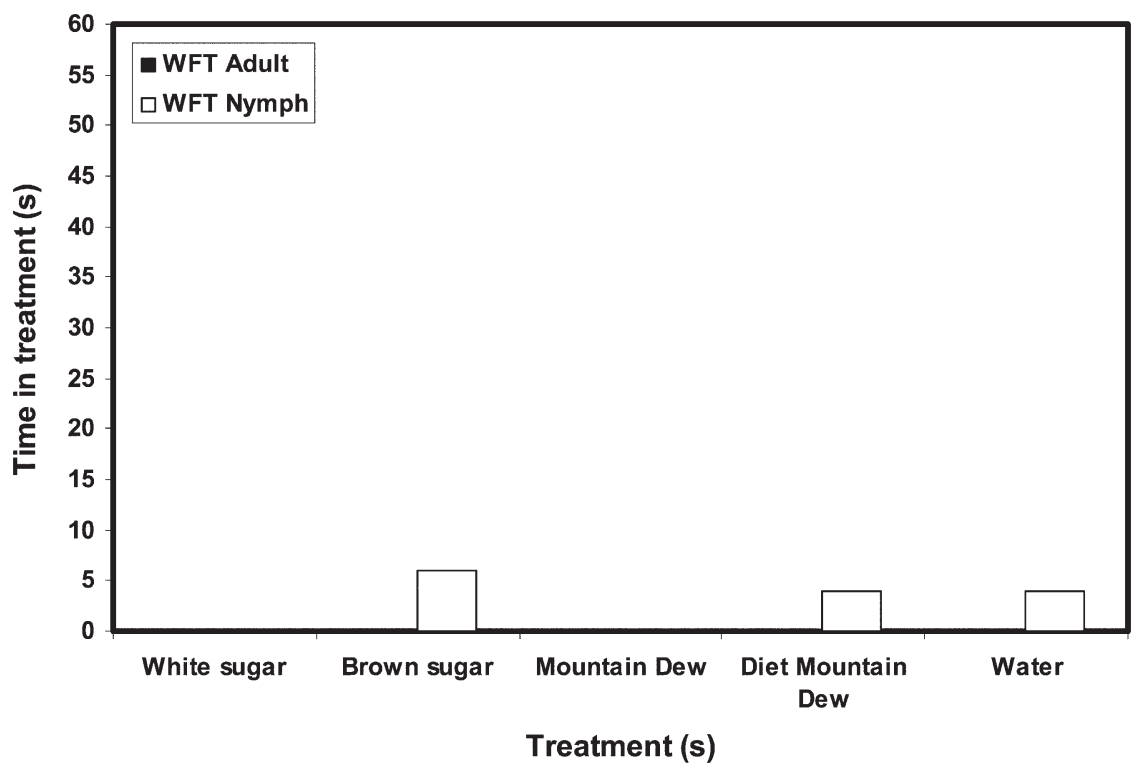

Fig. 4. Time spent (out of $300 \mathrm{~s}$ total) by western flower thrips (WFT) adult (black bars) and nymph (white bars) in each of the treatments (at the high rates) associated with the multiple-choice bioassays. Rates used were Mountain Dew (PepsiCo, Deep Gap, NC) at $0.36 \mathrm{~mL} / 100 \mathrm{~mL}(0.4608 \mathrm{fl} \mathrm{oz} / \mathrm{gal})$, Diet Mountain Dew at 0.36 $\mathrm{mL} / 100 \mathrm{~mL}$, white sugar at $0.24 \mathrm{~g} / 100 \mathrm{~mL}(0.3204 \mathrm{oz} / \mathrm{gal})$, and brown sugar at $0.24 \mathrm{~g} / 100 \mathrm{~mL}$. 
brown sugar ( 0.56 or $1.1 \mathrm{~g} / \mathrm{qt})$ as none of the other sugar-based compounds evaluated in Expt. 1 resulted in any mortality of western flower thrips. The treatments and rates used in the experiments are presented in Table 2 .

Seven days after application of the treatments, flowers were harvested, placed into plastic petri dishes $(14-\mathrm{cm}$ diameter) with lids, and then macerated under laboratory conditions. The numbers of live, dead, and total number of western flower thrips adults were counted. Percent mortality values for each treatment was calculated by dividing the number of dead western flower thrips by the total number recovered per flower (i.e., replicate). Percent mortality values were then normalized by arcsine square-root transformation and subject to a oneway analysis of variance (ANOVA) with treatment as the main effect (SAS version 9.1; SAS Institute, Cary, NC). Significant treatment means were separated using a Fisher's protected least significant difference (LSD) test at $P \leq 0.05$. All data presented are nontransformed.

\section{Results and discussion}

LABORATORY EXPERIMENTS. Western flower thrips adults and nymphs were not attracted to any of the sugar-based compound treatments regardless of rate (initial and high) based on the negligible (if any) amount of time spent ( $<60 \mathrm{~s}$ out of $300 \mathrm{~s}$ total) in any of the treatments (Figs. 1-4). These results were similar to the assays in which the insecticides were mixed with the sugar-based compounds as western flower thrips spent $\leq 29$ s across all the experiments out of $300 \mathrm{~s}$ total (Table 3 ). This is the reason why statistics were not conducted on the data.

Greenhouse experiments. There was no significant difference $(F=1.00 ; \mathrm{df}=8,44 ; P=0.4529)$ among the treatments in Expt. 1 as none of the sugar-based compounds provided any mortality of western flower thrips. In Expt. 2, although there was a significant difference $(F=$ 1019.97; $\mathrm{df}=9,49 ; P \leq 0.0001)$ among the treatments, the addition of Mountain Dew at the rate of $26.8 \mathrm{~mL} / 100 \mathrm{~mL}$ failed to enhance the efficacy of any of the treatments against western flower thrips (Fig. 5).

Table 3. Time in treatment spent by western flower thrips nymphs and adults associated with the initial rate (IR) [Mountain Dew (PepsiCo, Deep Gap, NC) at $0.18 \mathrm{~mL} / 100 \mathrm{~mL}(0.2304 \mathrm{fl} \mathrm{oz} / \mathrm{gal})$, Diet Mountain Dew at $0.18 \mathrm{~mL} / 100 \mathrm{~mL}$, white sugar at $0.12 \mathrm{~g} / 100 \mathrm{~mL}(0.1602 \mathrm{oz} / \mathrm{gal})$, and brown sugar at $0.12 \mathrm{~g} / 100 \mathrm{~mL}$ ] and high rate (HR) [Mountain Dew at 0.36 $\mathrm{mL} / 100 \mathrm{~mL}(0.4608 \mathrm{fl} \mathrm{oz} / \mathrm{gal})$, Diet Mountain Dew at $0.36 \mathrm{~mL} / 100 \mathrm{~mL}$, white sugar at $0.24 \mathrm{~g} / 100 \mathrm{~mL}(0.3204 \mathrm{oz} / \mathrm{gal})$, and brown sugar at $0.24 \mathrm{~g} / 100 \mathrm{~mL}$ ] of the sugar-based compounds, and the three insecticides [tau-fluvalinate at $8.0 \mathrm{fl} \mathrm{oz/}$ $100 \mathrm{gal}\left(0.625 \mathrm{~mL} \cdot \mathrm{L}^{-1}\right)$, pyridalyl at $8.0 \mathrm{oz} / 100 \mathrm{gal}\left(0.599 \mathrm{~g} \cdot \mathrm{L}^{-1}\right)$, and spinosad at $\left.6.0 \mathrm{fl} \mathrm{oz} / 100 \mathrm{gal}\left(0.468 \mathrm{~mL} \cdot \mathrm{L}^{-1}\right)\right]$. There were 10 replications per treatment for each insecticide and western flower thrips life stage.

\begin{tabular}{|c|c|c|c|c|c|c|c|c|c|c|c|c|}
\hline \multirow[b]{3}{*}{ Treatment } & \multicolumn{4}{|c|}{ Tau-fluvalinate } & \multicolumn{4}{|c|}{ Pyridalyl } & \multicolumn{4}{|c|}{ Spinosad } \\
\hline & \multicolumn{2}{|c|}{ Nymphs } & \multicolumn{2}{|c|}{ Adults } & \multicolumn{2}{|c|}{ Nymphs } & \multicolumn{2}{|c|}{ Adults } & \multicolumn{2}{|c|}{ Nymphs } & \multicolumn{2}{|c|}{ Adults } \\
\hline & IR & $\mathrm{HR}$ & $\mathrm{IR}$ & $\mathrm{HR}$ & IR & $\mathrm{HR}$ & IR & $\mathrm{HR}$ & IR & $\mathrm{HR}$ & IR & $\mathrm{HR}$ \\
\hline Diet Mountain Dew & 0.4 & 0.5 & 0.0 & 11.8 & 0.0 & 0.0 & 0.0 & 0.0 & 3.5 & 0.5 & 0.0 & 0.8 \\
\hline White sugar & 0.0 & 0.3 & 0.0 & 0.0 & 1.8 & 0.0 & 6.9 & 0.0 & 0.0 & 2.7 & 0.0 & 5.6 \\
\hline Brown sugar & 0.0 & 0.0 & 0.3 & 4.7 & 0.0 & 0.4 & 29.0 & 0.4 & 0.0 & 0.0 & 3.3 & 14.4 \\
\hline
\end{tabular}

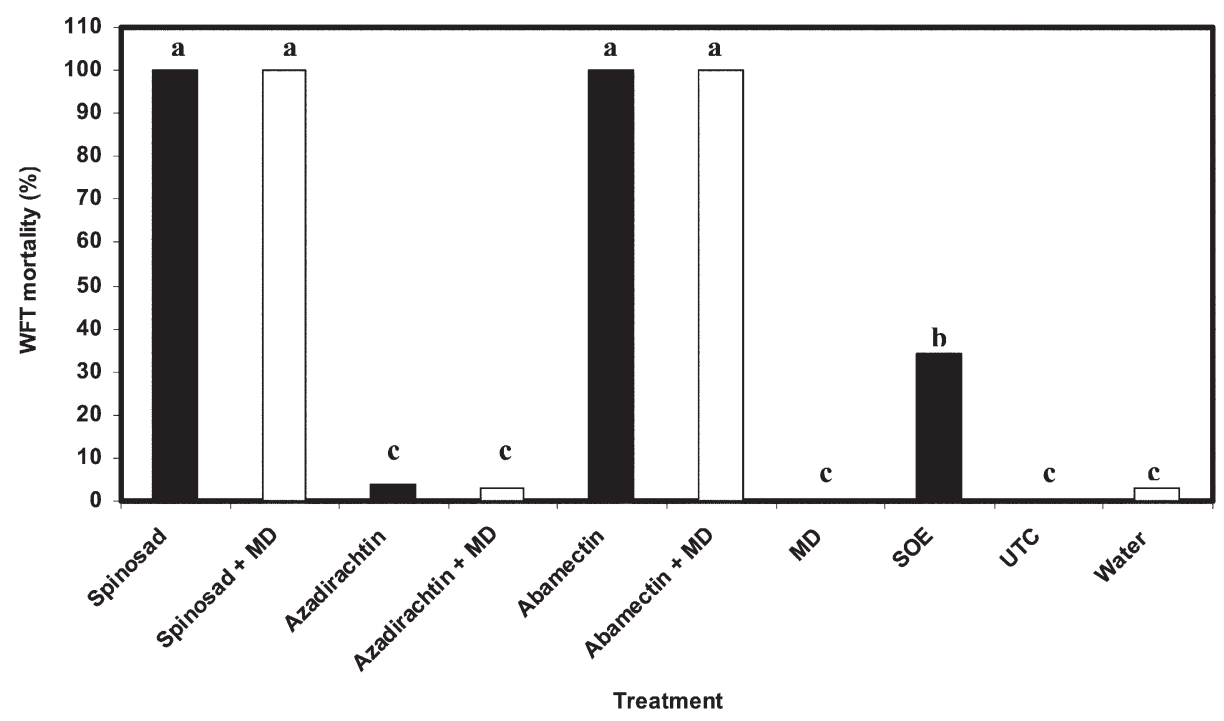

Fig. 5. Percent mortality of western flower thrips (WFT) for all treatments $7 \mathrm{~d}$ after application with five replications per treatment; MD = Mountain Dew (PepsiCo, Deep Gap, NC), UTC = untreated control, Water = water control. Insecticides used were spinosad, azadirachtin, abamectin, and sucrose octanoate ester (SOE). Rates used are listed in Table 1. Bars with common letters are not significantly different from each other $(P \geq 0.05)$ based on Fisher's protected least significant difference mean separation test. 
However, it was difficult to assess if mixing Mountain Dew had any real effect since the spinosad and abamectin individual treatments provided nearly $100 \%$ mortality of the western flower thrips. The addition of Mountain Dew did not enhance the efficacy of azadirachtin as percent mortality was $<10 \%$ for both treatments (Fig. 5). The sucrose octanoate ester (SucraShield ${ }^{\mathrm{TM}}$ ) treatment provided $<40 \%$ mortality of western flower thrips.

Treatment was significant for Expt. $3(F=24.27 ; \mathrm{df}=9,49 ; P \leq 0.0001)$ and Expt. $4(F=43.6 ; \mathrm{df}=9,49 ; P \leq$ $0.0001)$; however, the addition of the initial and high rate of either Mountain Dew or brown sugar did not enhance western flower thrips mortality for any of the insecticide treatments (Table 4).

This study is the first to quantitatively demonstrate that western flower thrips adults and nymphs are not attracted to sugar-based compounds because of the lack of retention time in any of the treatments and treatment combinations in the laboratory experiment, and based on greenhouse experiments; there was no significant increase in efficacy or enhancement associated with western flower thrips mortality when the insecticides evaluated were mixed with either the initial or high rate of Mountain Dew or brown sugar.

Western flower thrips prefer to feed on pollen, which is essential for larval growth, sexual maturation, and egg-laying (Andrewartha and Kilpatrick, 1951; Bournier et al., 1979; Murai and Ishii, 1982). In addition, protein nitrogen is the primary food source required by insects (McNeill and Southwood, 1978) and results in a general increase in the rate of survival, growth, and reproduction (Strong et al., 1984). Although the form and availability of nitrogen may affect insects, total nitrogen is a viable indicator of the nutritional value of plants (Kirk, 1997a,b). A sugar may not provide any

Table 4. Percent western flower thrips (WFT) mortality associated with each individual insecticide treatment (tau-fluvalinate, pyridalyl, and spinosad) and in combination with both the high rate $(\mathrm{HR})$ and initial rate (IR) of Mountain Dew (PepsiCo, Deep Gap, NC) [0.36 mL/100 mL (0.4608 fl oz/gal) and $0.18 \mathrm{~mL} /$ $100 \mathrm{gal}(0.2304 \mathrm{fl} \mathrm{oz} / \mathrm{gal})]$ for Expt. 3 and brown sugar $[0.24 \mathrm{~g} / 100 \mathrm{~mL}$ $(0.3204 \mathrm{oz} / \mathrm{gal})$ and $0.12 \mathrm{~g} / 100 \mathrm{~mL}(0.1602 \mathrm{oz} / \mathrm{gal})]$ for Expt. 4 .

\begin{tabular}{llc}
\hline \multicolumn{2}{c}{ Expt. 3} \\
\hline Treatment & Rate (per quart) & \\
\hline Tau-fluvalinate & $0.51 \mathrm{~mL}$ & $\begin{array}{r}\text { WFT mortality } \\
\text { [mean } \pm \text { se (\%) }\end{array}$ \\
Pyridalyl & $0.56 \mathrm{~g}$ & $4 \pm 2 \mathrm{c}^{\mathrm{y}}$ \\
Spinosad & $0.44 \mathrm{~mL}$ & $62 \pm 13 \mathrm{~b}$ \\
Tau-fluvalinate + Mountain Dew (HR) & $0.51 \mathrm{~mL}+3.4 \mathrm{~mL}$ & $98 \pm 10 \mathrm{a}$ \\
Pyridalyl + Mountain Dew (HR) & $0.56 \mathrm{~g}+3.4 \mathrm{~mL}$ & $1 \pm 1 \mathrm{c}$ \\
Spinosad + Mountain Dew (HR) & $0.44 \mathrm{~mL}+3.4 \mathrm{~mL}$ & $63 \pm 13 \mathrm{~b}$ \\
Tau-fluvalinate + Mountain Dew (IR) & $0.51 \mathrm{~mL}+1.7 \mathrm{~mL}$ & $13 \pm 5 \mathrm{c}$ \\
Pyridalyl + Mountain Dew (IR) & $0.56 \mathrm{~mL}+1.7 \mathrm{~mL}$ & $66 \pm 11 \mathrm{~b}$ \\
Spinosad + Mountain Dew (IR) & $0.44 \mathrm{~mL}+1.7 \mathrm{~mL}$ & $93 \pm 4 \mathrm{a}$ \\
Untreated control & \multicolumn{1}{c}{-} & $0 \pm 0 \mathrm{c}$
\end{tabular}

Expt. 4

\begin{tabular}{llc}
\hline Treatment & Rate (per quart) & $\begin{array}{c}\text { WFT mortality } \\
\text { [mean } \pm \text { SE (\%)] }\end{array}$ \\
\hline Tau-fluvalinate & $0.51 \mathrm{~mL}$ & $6 \pm 2 \mathrm{de}^{\mathrm{y}}$ \\
Pyridalyl & $0.56 \mathrm{~g}$ & $48 \pm 16 \mathrm{~b}$ \\
Spinosad & $0.44 \mathrm{~mL}$ & $100 \pm 0 \mathrm{a}$ \\
Tau-fluvalinate + brown sugar (HR) & $0.51 \mathrm{~mL}+1.1 \mathrm{~g}$ & $7 \pm 3 \mathrm{de}$ \\
Pyridalyl + brown sugar (HR) & $0.56 \mathrm{~g}+1.1 \mathrm{~g}$ & $53 \pm 9 \mathrm{bc}$ \\
Spinosad + brown sugar (HR) & $0.44 \mathrm{~mL}+0.56 \mathrm{~g}$ & $100 \pm 0 \mathrm{a}$ \\
Tau-fluvalinate + brown sugar (IR) & $0.51 \mathrm{~mL}+0.56 \mathrm{~g}$ & $5 \pm 1 \mathrm{de}$ \\
Pyridalyl + brown sugar (IR) & $0.56 \mathrm{~g}+0.56 \mathrm{~g}$ & $30 \pm 6 \mathrm{~cd}$ \\
Spinosad + brown sugar (IR) & $0.44 \mathrm{~mL}+0.56 \mathrm{~g}$ & $95 \pm 3 \mathrm{a}$ \\
Untreated control & \multicolumn{1}{c}{-} & $0 \pm 0 \mathrm{e}$ \\
\hline
\end{tabular}

${ }^{2} 1 \mathrm{~mL} / \mathrm{qt}=0.1353 \mathrm{fl} \mathrm{oz} / \mathrm{gal}=1.0567 \mathrm{~mL} \cdot \mathrm{L}^{-1}, \mathrm{l} \mathrm{g} / \mathrm{qt}=0.1411 \mathrm{oz} / \mathrm{gal}=1.0567 \mathrm{~g} \cdot \mathrm{L}^{-1}$

'Means followed by a common letter are not significantly different from each other $(P \leq 0.05)$ based on Fisher's protected least significant difference (LSD) mean separation test.

essential nutrients (proteins) required for development and reproduction (Kirk, 1995). For example, the oviposition rate of the banded greenhouse thrips (Hercinothrips femoralis) adult females declined from one egg per $12 \mathrm{~h}$ to zero over a 2 - to 3 -d period after feeding on a sucrose solution (Laughlin, 1971).

The insecticides used in the study were selected because they are all labeled for control of western flower thrips, vary in their efficacy against western flower thrips, and are in different chemical classes with distinct modes of action (Abalis et al., 1986; Salgado, 1997, 1998; Verkerk and Wright, 1993; Ware and Whitacre, 2004; Yu, 2008). In addition, these insecticides are widely used by greenhouse producers against western flower thrips (R.A. Cloyd, unpublished data). Although pyrethroid insecticides such as tau-fluvalinate may have repellent properties (Hall, 1979; Hull and Starner, 1983; Thompson and Wilkins, 2003), this did not appear to be a factor in our study as, in general, there was no difference in the time spent (retention time) among the insecticide and sugarbased compound treatments (Table 3 ).

The sucrose octanoate esters $\left(\right.$ SucraShield ${ }^{\mathrm{TM}}$ ) treatment was included in Expt. 2 because it is a sugar-based compound that is registered for thrips. The a.i. is an extract from the leaf hairs of wild tobacco (Nicotiana gossei) plants (Neal et al., 1994). In previous studies, we have found minimal efficacy against both the nymph and adult life stages of western flower thrips (Cloyd, 2009; R.A. Cloyd, unpublished data). In Expt. 2 of the current study, the product provided $<40 \%$ mortality of western flower thrips (Fig. 5).

Alternative products containing attractants/stimulants or alarm pheromones are commercially available against mite pests such as the twospotted spider mite (Tetranychus urticae). For example, the product Stirrup $\mathrm{M}^{\circledR}$ (Troy Biosciences, Phoenix, AZ) contains the alarm pheromone farnesol, which is suppose to increase mite activity and thus enhance exposure to miticide applications in addition to reducing mite feeding (Regev and Cone, 1975). In addition, there is a product called Konsume $^{\circledR}$ (Troy Biosciences) that may act as a feeding stimulant thus increasing exposure to spray residues. This is a similar concept to the mixing of sugarbased compounds with insecticides 
to suppress western flower thrips populations.

In conclusion, this study has demonstrated that western flower thrips adults and nymphs are not attracted to sugar-based compounds and as such there is no benefit of adding these types of materials into spray solutions designated for control of western flower thrips. Therefore, when using insecticides to deal with western flower thrips, greenhouse producers need to obtain thorough coverage of all plant parts, apply insecticides frequently enough, and rotate insecticides with different modes of action to avoid populations developing resistance (Heugens et al., 1989; Jensen, 2000; Lewis, 1997; Loughner et al., 2005; Seaton et al., 1997; Zhao et al., 1995).

\section{Literature cited}

Abalis, I.M., A.T. Eldefrawi, and M.E. Eldefrawi. 1986. Actions of avermectin $B_{1 a}$ on the $\gamma$-aminobutyric acidA receptor and chloride channels in the rat brain. J. Biochem. Toxicol. 1:69-82.

Andrewartha, H.G. and D.T. Kilpatrick. 1951. The apple thrips. J. Agr. South Australia 54:586-592.

Bournier, A., A. Lacasa, and Y. Pivot. 1979. Régime alimentaire d'un thrips prédateur Aeolothrips intermedius (Thysanotera: Aeolothripidae). Entomophaga 24:353-361

Brodsgaard, H.F. 1989. Frankliniella occidentalis (Thysanoptera: Thripidae): A new pest in Danish greenhouses. A review. Tidsskr. Planteavl 93:83-91.

Brodsgaard, H.F. 2004. Biological control of thrips on ornamental crops, p. 253-264. In: Heinz, K.M., R.G. Van Driesche, and M.P. Parrella (eds.). Biocontrol in protected culture. Ball Publishing, Batavia, IL.

Childers, C.C. 1997. Feeding and oviposition injuries to plants, p. 505-537. In: T. Lewis (ed.). Thrips as crop pests. CAB International, Wallingford, UK.

Cloyd, R.A. 2009. Does dew do it? GrowerTalks 72(10):76-79.

FitDay-Myth or Fact. 2011. Brown sugar is better than white sugar. 11 Oct. 2011. $<$ http://www.fitday.com/fitness-articles/ nutrition/healthy-eating/myth-or-factbrown-sugar.html>.

Georghiou, G.P. 1986. The magnitude of the resistance problem, p. 14-43. In: Pesticide resistance: Strategies and tactics for management. National Academy of Sciences, Washington, DC.
Gerin, C., T.H. Hance, and G. Van Impe. 1994. Demographical parameters of Frankliniella occidentalis (Pergande) (Thysanoptera: Thripidae). J. Appl. Entomol. 118:370-377.

Hall, F.R. 1979. Effects of synthetic pyrethroids on major insect and mite pests of apple. J. Econ. Entomol. 72:441-446.

Helyer, N.L., P.J. Brobyn, P.N. Richardson, and R.N. Edmondson. 1995. Control of western flower thrips (Frankliniella occidentalis Pergande) pupae in compost. Ann. Appl. Biol. 127:405-412.

Herron, G.A. and T.M. James. 2005. Monitoring insecticide resistance in Australian Frankliniella occidentalis Pergande (Thysanoptera: Thripidae) detects fipronil and spinosad resistance. Aust. J. Entomol. 44:299-303

Heugens, A., G. Buysse, and D. Vermaerke. 1989. Control of Frankliniella occidentalis on Chrysanthemum indicum with pesticides. Mededelingen van de Faculteit Landbouwwetenschappen Rijksuniversiteit Gent 54:975-981.

Hull, L.A. and V.R. Starner. 1983. Impact of four synthetic pyrethroids on major natural enemies and pests of apple in Pennsylvania. J. Econ. Entomol. 76: 122-130.

Jensen, S.E. 2000. Insecticide resistance in the western flower thrips, Frankliniella occidentalis. Integrated Pest Mgt. Rev. 5: 131-146.

Kirk, W.D.J. 1985. Pollen-feeding and the host specificity and fecundity of flower thrips (Thysanoptera). Ecol. Entomol. 10: 281-289.

Kirk, W.D.J. 1987. How much pollen can thrips destroy? Ecol. Entomol. 12:31-40.

Kirk, W.D.J. 1995. Feeding behavior and nutritional requirements, p. 21-29. In: B.L. Parker, M. Skinner, and T. Lewis (eds.). Thrips biology and management. Plenum Press, New York.

Kirk, W.D.J. 1997a. Feeding, p. 119-174. In: T. Lewis (ed.). Thrips as crop pests. $\mathrm{CAB}$ International, Wallingford, UK

Kirk, W.D.J. 1997b. Distribution, abundance and population dynamics, p. 217257. In: T. Lewis (ed.). Thrips as crop pests. $C A B$ International, Wallingford, UK

Laughlin, R. 1971. A culture method for Hercinothrips femoralis (Reuter) (Thysanoptera). J. Aust. Entomol. Soc. 10:301303.

Lewis, T. 1997. Chemical control, p. 567-593. In: T. Lewis (ed.). Thrips as crop pests. CAB International, Wallingford, UK.
Loughner, R.L., D.F. Warnock, and R.A. Cloyd. 2005. Resistance of greenhouse, laboratory, and native populations of western flower thrips to spinosad. HortScience 40:146-149.

McNeill, S. and T.R.E. Southwood. 1978. The role of nitrogen in the development of insect/plant relationships, p. 77-98. In: J.B. Harborne (ed.). Biochemical aspects of plant and animal coevolution. Academic Press, London.

Mound, L.A. 1996. The thysanoptera vector species of tospoviruses. Acta Hort. 431:298-309.

Murai, T. and T. Ishii. 1982. Simple rearing method for flower thrips (Thysanoptera: Thripidae) on pollen. Jpn. J. Appl. Entomol. Zool. 26:149-154.

Neal, J.W., J.G. Buta, G.W. Pittarelli, W.R. Lusby, and J.A. Bentz. 1994. Novel sucrose esters from Nicotiana gossei: Effective biorationals against selected horticultural insect pests. J. Econ. Entomol. 87:1600-1607.

Parrella, M.P. 1995. IPM: Approaches and prospects, p. 357-363. In: B.L. Parker, M. Skinner, and T. Lewis (eds.). Thrips biology and management. Plenum Press, New York.

Parrella, M.P. and B. Murphy. 1996. Western flower thrips: Identification, biology and research on the development of control strategies. Bul. Intl. Organization Biol. Control 19:115-118.

Regev, S. and W.W. Cone. 1975. Evidence of farnesol as a male sex attractant for the two spotted spider mite, Tetranychus urticae Koch. Environ. Entomol. 4: 307-311.

Salgado, V.L. 1997. The modes of action of spinosad and other insect control products. Down To Earth (Waukesha) 52:3543.

Salgado, V.L. 1998. Studies on the mode of action of spinosad: Insect symptoms and physiological correlates. Pestic. Biochem. Physiol. 60:91-102.

Seaton, K.A., D.F. Cook, and D.C. Hardie. 1997. The effectiveness of a range of insecticides against western flower thrips (Frankliniella occidentalis) (Thysanoptera: Thrididae) on cut flowers. Aust. J. Agr. Res. 48:781-787.

Strong, D.R., J.H. Lawton, and T.R.E. Southwood. 1984. Insects on plants: Community patterns and mechanisms. Blackwell Scientific Publications, Oxford, UK.

Thompson, H. and S. Wilkins. 2003. Assessment of the synergy and repellency of pyrethroid/fungicide mixtures. Bull. Insectology 56:131-134. 


\section{Research Reports}

Tommasini, M.G. and S. Maini. 1995. Frankliniella occidentalis and thrips harmful to vegetable and ornamental crops in Europe, p. 1-42. In: A.J.M. Loomans, J.C. van Lenteren, S. Tommasini, S. Maini, and J. Riudavets (eds.). Biological control of thrips tests. Wageningen Univ., Wageningen, The Netherlands.

Trichilo, P.J. and T.F. Leigh. 1988. Influence of resource quality on the reproductive fitness of flower thrips (Thysanoptera:
Thripidae). Ann. Entomol. Soc. Am. 81: 64-70.

Verkerk, R.H.J. and D.J. Wright. 1993. Biological activity of neem seed kernel extracts and synthetic azadirachtin against larvae of Plutella xylostella L. Pestic. Sci. 37:83-91.

Ware, G.W. and D.M. Whitacre. 2004. The pesticide book. MeisterPro Information Resources, Willoughby, $\mathrm{OH}$.
$\mathrm{Yu}$, S.J. 2008. The toxicology and biochemistry of insecticides. CRC Press, Boca Raton, FL.

Zhao, G., W. Liu, J.M. Brown, and C.O. Knowles. 1995. Insecticide resistance in field and laboratory strains of western flower thrips (Thysanoptera: Thripidae). J. Econ. Entomol. 88:1164-1170. 